\title{
Henry Ford: Engineer and Entrepreneur
}

\author{
Sorin-George Toma ${ }^{1}$, Andreea Simona Săseanu ${ }^{2}$ and \\ Carmen Cristina Runceanu-Albu ${ }^{3}$ \\ ${ }^{1)}$ University of Bucharest, Bucharest, Romania. \\ 2) The Bucharest University of Economic Studies, Bucharest, Romania. \\ ${ }^{3)}$ Transilvania University, Brașov, Romania \\ E-mail: tomagsorin62@yahoo.com; E-mail: saseanu@yahoo.com; \\ E-mail: carmen.albu@unitbv.ro
}

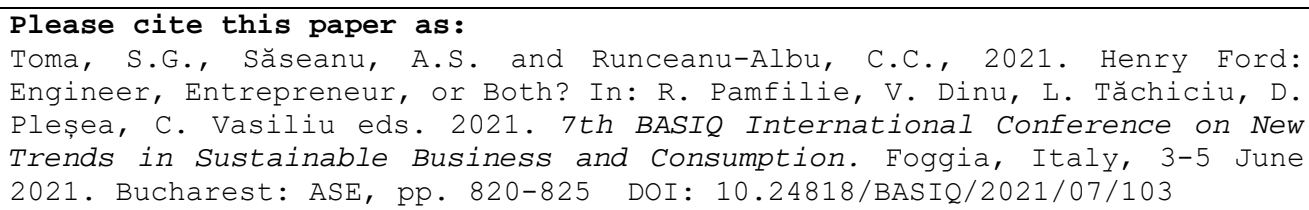

\begin{abstract}
Since its emergence, the automobile has captured the attention of the entire world and, consequently, led to the birth of a very dynamic industry, the automotive industry. In the beginning, the price was not affordable for many people and, therefore, the automobile was the appanage of the upper class. The cost of the cars significantly decreased over time and mass selling grew rapidly due to mass production. The Fordist production system stimulated consumption and eventually created a mass market for cars both in America and in the whole world. The paper aims to to define the concepts of engineer and entrepreneur, to identify their common features and to illustrate them in the case of an iconic personality of America. The authors achieved the objectives of the paper through a quantitative research method and a case study. The results of the paper provide a better understanding of the two concepts by highlighting their common characteristics. Also, they punctuate these common features in the case of Henry Ford.
\end{abstract}

\section{Keywords}

Henry Ford, entrepreneur, engineer, automobile, automobile industry

DOI: 10.24818/BASIQ/2021/07/103

\section{Introduction}

Few inventions contributed to the transformation of the life of human beings than the motor vehicle. Since its emergence, the automobile has captured the attention of the entire world and, consequently, led to the birth of a very dynamic industry, the automotive industry. In the mid-1880s, Karl Friedrich Michael Benz, a German mechanical engineer, designed and built the first true automobile in human history (Roser, 2017). The manufacturing techniques and methods of early automobiles were similar to craft traditions. This is why, in the beginning, the price was not affordable for many people and, therefore, the automobile was the appanage of the upper class.

The cost of the cars significantly decreased over time and mass selling grew rapidly due to mass production. This was the result of a mixture of advancements in theory and practice. On the one hand, F. W Taylor, the father of scientific management, published its time and motion studies in the United States of America (USA) and designed an efficiency model that deeply influenced businesses in the long term (Mayo and Nohria, 2005; Toma, et al., 2014; Toma, 2015). On the other hand, Henry Ford, the father of mass production, launched its famous gasoline-powered low-priced Model $\mathrm{T}$ of the last century (Brown, 2002; Votolato, 2015). The Fordist production system stimulated consumption and eventually created a mass market for cars first in America, and after, in the whole world (Flink, 1990; Toma, 2005). Thus, motor vehicles became the most used means of transportation. The US automotive 
industry highly contributed to the mass production system that replaced the old craft system not only through the design and implementation of efficient methods of production and work but also through the appearance and development of three corporations (Ford Motor, General Motors, and Chrysler) that maintained strict control over the whole production process.

The last decades of the twentieth century witnessed the emergence and spread of the Japanese lean production system epitomized by Toyota Motor (Rubenstein, 2001; Naruo and Toma, 2007; Marinescu and Toma, 2008; Toma and Naruo, 2017). As technology has rapidly evolved, cars started to be increasingly controlled by electronics and artificial intelligence rather than by human beings.

For more than a century, the car has represented not only a prevailing powerful catalyst for change in other industries but also a tool of measuring national prestige in a highly competitive world (Design Museum, 2011). Despite its rather short history, the automotive industry has become a global industry as the manufacturing, selling, and servicing of motor vehicles and automobiles developed into numerous businesses around the world and a plethora of automakers has appeared and, especially from America, Asia, and Europe, are competing fiercely worldwide (Erjavec, 2010). Moreover, many other businesses depend on the automobile and motor vehicle industry to obtain their inputs or to provide their product and/or services (Rubenstein, 2014).

The paper aims to define the concepts of engineer and entrepreneur, to identify their common features and to illustrate them in the case of Henry Ford, one of the iconic personalities of America. The remainder of the paper is structured as follows: the second part of the paper presents the literature review. The third part of the paper exposes the research methodology. The results of the research are shown in the fourth part of the paper. The paper ends with conclusions.

\section{Literature review}

There are a huge number of articles and books regarding the concepts of engineer and entrepreneur. Consequently, a plethora of definitions linked to these concepts can be found in the literature.

An engineer is a person who is "a member of the engineering profession, that is, a member both of an occupation that is engineering by "birth," "adoption," or "marriage" and of the profession committed to engineering's code of ethics" (Davis, 1996, p.97), is committed "to change, to modify or convert the world represented by a different one" (Koen, 1985, p.11), integrates "different types of skills and knowledge in an effort to solve ill-structured problems that meet people's needs" (Capobianco, et al., 2011, p.306) and "designs devices, components, subsystems, and systems and, to create a successful design, in the sense that it leads directly or indirectly to an improvement in our quality of life, must work within the constraints provided by technical, economic, business, political, social, and ethical issue" (National Academy of Engineering, 2004, p.7).

Often considered as the founder of a new business (Barton Cunningham and Lischeron, 1991) and an agent of change, an entrepreneur is an individual who recognizes ,opportunities where others see chaos, contradiction and confusion” (Frederick, et al., 2019, p.3) and a „practical and efficient person” (Dollinger, 2008, p.34) who ,,assumes the risk associated with uncertainty...and supplies financial capital” (Hébert and Link, 2006, p.264). In other words, an entrepreneur is ,the founder or ownermanager of a small or medium-sized enterprise (SME) with growth potential” (Casson, et al., 2010, p.6) who ,perceives an opportunity and creates an organization to pursue it” (Bygrave and Hofer, 1991, p.13).

Based on the above considerations, there are some common characteristics of the two concepts. Firstly, both concepts are related to change. Entrepreneurs and engineers are important agents of change. Secondly, engineers and entrepreneurs are doers and creators. Thirdly, engineering and entrepreneurship are nowadays global professions (Bourn, 2018; Frederick, et al., 2019). Fourthly, entrepreneurs and engineers are adding value to society in their attempt to solve its multiple problems (National Society of Professional Engineers, 2013; Filion, 2021).

Most of these common characteristics of the two above concepts are personified by Henry Ford. Born in 1963, he grew up in a rural and wild environment on his parents' farm located in Springwells Township, Michigan. His parents, William and Mary Litogot Ford worked hard on the farm's land 
(Nevins, 1954). It is said that "it was the potential of machines to ease the lives of farmers that first drew Ford to engineering, and that would continue to inspire his work and focus his business endeavors all his life" (Brinkley, 2003, p.4). Henry spent his childhood showing a passion for tinkering- his toys were tools and pieces of machinery. Two big events marked his life when he turned twelve years old: the acquisition of a watch and the encounter with a Nichols and Shepard road engine (Brands, 1999). Thus, he decided to build a reliable and affordable car for the many (Bailey, 2016).

His early interest in mechanics made Henry arrange a small machine workshop. Later, he was employed as a machinist's apprentice and eventually became an engineer at the Edison Illuminating Company of Detroit (Ford, 1925). Henry worked, read, and got close acquainted with engines.

After he got married in 1885 to Clara Jane Bryant, a true wheel of the balance of his conjugal life (Sorensen, 2006), Henry started to think about building his first cars. His obsessive and profound interest in engines and motor vehicles made him feel that he was "on to something new, different, and better than others who were experimenting with the horseless carriage" (Tedlow, 2003, p.148). During the day Henry was employed as a mechanic, and he used to experiment with his ideas especially during the night. In 1893, Henry manufactured by himself a small one-cylinder gasoline engine (Ford, 2012) and by mid-1896, he succeeded in building a quadricycle, a self-propelled car. Thus, he demonstrated he was a brilliant inventor who created, in essence, the complete car out of nothing (Winicott, 2015). A partisan of hard- working and continuous improvement (Sinclair, 1938), he built his second car in 1898, being strongly encouraged by Thomas Alva Edison.

After quitting Edison Illuminating Company, Henry established Detroit Automobile Company in 1899, together with William H. Murphy without gaining business success (Bersinger, 2018). In 1901, he designed, constructed, and drove an automobile, winning a race against the champion Alexander Winton. With the help of several investors, Henry opened a new business, Henry Ford Company, in the same year. Appointed chief engineer, he left the company one year later.

After forming a partnership with Alexander Y. Malcomson, Henry and a group of investors finally established Ford Motor Company in Detroit, in 1903. He was in charge of car design, engineering and production, and James Couzens of business matters. In this respect, "on the factory floor Ford was supreme; in the offices Couzens oversaw the bookkeeping, wrote letters, paid bills, collected money due, and after mid-November supervised sales" (Nevins, 1954, p.243). As the demand for automobiles increased, the company succeeded in obtaining profits and, therefore, in financing itself by its revenues. Henry also continued to construct new racing cars and set a land speed record of around 91 miles per hour.

In his long battle for building a cheap automobile, Henry proved his extraordinary mechanical engineering talent and, eventually, launched the famous Model T. It had an engine of four-cylinder and 20horse-power, and soon became the archetype of the stable and low-cost American car. By providing the first inexpensive car for millions of American people (Snow, 2013), Henry saw his dream came true. In other words, Model T represented "the culmination of Henry Ford's long-standing determination to produce a light, sturdy, inexpensive car for the American people" (Watts, 2006, p.142) and "its gutturals and verbs and lamentations and chortling - were the overtones of the American way of life" (Garrett, 1952, p.32).

The mid-1920s witnessed the world domination of Ford Motor Company when approximately half of all cars were produced there (Mayo and Nohria, 2005). Henry Ford became one of the wealthiest businessmen in the world. He died in 1947.

\section{Research methodology}

The authors achieved the objectives of the paper through a quantitative research method and a case study. The needed information was gathered through desk research. In the beginning, a plethora of secondary data was collected from various sources. Then, these data were classified and analysed by the use of a literature review. The main sources were journals (e.g., Journal of Small Business Management, Entrepreneurship Theory and Practice) and books from well-known publishing houses (e.g., Harvard Business School, Edward Elgar Publishing), from the fields of entrepreneurship, economics, history. These were found mostly in electronic databases (e.g., SAGE, Springer) and 
libraries (e.g., the Central University Library Carol I of Bucharest). Finally, the data were synthesized in order to conclude the paper.

\section{Results and discussion}

Starting from the literature review, the authors analysed and synthesized the collected data and reached several results. Firstly, the concepts of engineer and entrepreneur share some common characteristics, such as their emphasis on creativity and provoking change. Secondly, Henry Ford was a gifted, ingenious, hard-working and exceptional mechanical engineer. This assertion is based on the following facts:

- Since his childhood, Ford used to play with pieces of machinery, showing a deep passion for tinkering and an ardent curiosity towards mechanics.

- Fascinated by watches, he dismembered them and easily put all their pieces together again. As an authentic self-made man, he learned by himself to repair watches when he was only 15years old.

- Fate played its role in his prodigious life when Ford encountered a motor vehicle as a boy. He proved to be so excited that he decided to build himself a car.

- He got a lot of mechanical experience during his employment period. Initially, he was employed as an apprentice machinist, later as a mechanic and, finally, as a chief engineer.

- The many and long hours Ford spent in his workshop in making automobile experimentation highly contributed to designing and constructing his future cars.

- He always tried to improve the cars he built during the time.

- Ford adapted the assembly line for mass production in the automotive industry and invented the tools he needed to reach the mechanical advances he bore in mind.

- His searing passion for mechanics drove him to expand his work in the whole motor vehicle industry. His major personal endeavours include besides automobiles tractors, ambulances and aircraft engines.

Thirdly, Henry Ford was also a successful entrepreneur. The basis of this statement is sustained by the following elements:

- In his youth, Ford had the chance to meet and learn from several prosperous entrepreneurs and businessmen, such as Thomas Alva Edison.

- He was a man of vision because he understood that the future of America will be 'on the wheels'.

- As a true entrepreneur, Ford fully believed in putting into practice his ideas.

- He had great confidence in his working capacity.

- Ford showed a huge desire to succeed in his business ventures in spite of his failures.

- He strongly believed that his products- the cars- will change the world.

- Ford was a change agent within the American business world when he launched his famous Model T.

- His pursuit of operational efficiency led him to mass selling and allowed him to stimulate mass consumption of automobiles.

All in all, Henry Ford was a brilliant engineer and a very wealthy entrepreneur.

\section{Conclusions}

Since its relatively short appearance, the automobile has led to the birth of a complex industry and revolutionized the world economy. The automotive industry has transformed into a global multi-billion dollars business. Therefore, the automobile has been a topic of interest for an impressive number of studies and researches worldwide from both the economic and engineering side.

The paper conduces through its theoretical contributions to the enrichment of the scientific literature. First, it offers a better understanding of the concepts of engineer and entrepreneur by emphasizing their common characteristics. Second, the paper illustrates these common features in the case of a famous American engineer and entrepreneur, Henry Ford. 
The limits of the paper are given by the fact that only some of the facets of the two concepts were analysed. Also, the complex relationship between them might be illustrated by taking into account the case of other iconic entrepreneurs and engineers. Further researches might identify and take into account other issues related to the relationship between the two above concepts and exemplify them in the case of other representative personalities.

\section{References}

Bailey, D., 2016. How the Automobile Changed History. Minneapolis, MN: Abdo Publishing.

Barton Cunningham, J. and Lischeron, J., 1991. Defining entrepreneurship. Journal of Small Business Management, 29(1), pp.45-61.

Bersinger, S., 2018. Les Entrepreneurs de Légende: Thomas Edison, Henry Ford, Steve Jobs...Partis de rien, ils ont changé le monde. Paris: Enrick B. Editions.

Bourn, D., 2018. The global engineer. In: D. Bourn, 2018. Understanding Skills for $21^{\text {st }}$ Century Professions. Cham: Palgrave Macmillan. pp.201-219.

Boyer, R. and Durand, J.-P., 1997. After Fordism. Hampshire: MacMillan.

Brands, H. W., 1999. Masters of Enterprise: Giants of American Business from John Jacob Astor and J. P. Morgan to Bill Gates and Oprah Winfrey. New York, NY: The Free Press.

Brinkley, D., 2004. Wheels for the World.: Henry Ford, His Company, and a Century of Progress 1903-2003. London: Penguin Books.

Brown, D. E., 2002. Inventing Modern America: From the Microwave to the Mouse. Cambridge, MA: The MIT Press.

Bygrave, W. D. and Hofer, C. W., 1991. Theorizing about entrepreneurship. Entrepreneurship Theory and Practice, 16(2), pp.13-22.

Capobianco, B.M., Diefes-Dux, H.A., Mena, I. and Weller, J., 2011. What is an engineer? Implications of elementary school student conceptions for engineering education. Journal of Engineering Education, 100(2), pp.304-328.

Casson, M., Buckley, P.J., Dark, K., Della Giusta, M., Godley, A., Gulamhussen, M.A., da Silva Lopes, T. and Wadeson, N., 2010. Entrepreneurship: Theory, Networks, History. Cheltenham: Edward Elgar Publishing.

Davis, M., 1996. Defining “engineer": How to do it and why it matters. Journal of Engineering Education, 85(2), pp.97-101.

Design Museum, 2011. Fifty Cars that Changed the World. [e-book] London: Octopus Publishing Group.

Dollinger, M.J., 2008. Entrepreneurship: Strategies and Resources. 4th edition. Lombard, IL: Marsh Publications

Erjavec, J., 2010. Automotive Technology: A Systems Approach. $5^{\text {th }}$ edition. New York, NY: Delmar, Cengage Learning.

Filion, L.J., 2021. Defining the entrepreneur. In: L.-P. Dana, 2021. World Encyclopaedia of Entrepreneurship. Cheltenham: Edward Elgar Publishing. pp.72-83.

Flink, J.J., 1990. Henry Ford and the triumph of the automobile. In: C. W. Pursell, ed. 1990. Technology in America: A History of Individuals and Ideas. Cambridge, MA: The MIT Press. pp.177-189.

Ford, H., 1925. Ma Vie et Mon Oeuvre. Paris: Payot.

Ford, H., 2012. Today and Tomorrow. Hawthorne, CA: BN Publishing.

Frederick, H., O'Connor, A. and Kuratko, D. F., 2019. Entrepreneurship. $5^{\text {th }}$ Asia-Pacific edition. Melbourne: Cengage Learning Australia. 
Garrett, G., 1952. The Wild Wheel. New York, NY: Pantheon Books.

Hébert, R.F. and Link, A.N., 2006. Historical perspectives on the entrepreneur. Foundation and Trends in Entrepreneurship, 2(4), pp.261-248.

Koen, B.V., 1985. Definition of the Engineering Method. Washington, DC: American Society for Engineering Education. [pdf] Available at: <https:/files.eric.ed.gov/fulltext/ ED276572.pdf $>$ [Accessed 3 April 2021].

Marinescu, P. and Toma, S.G., 2008. Implementing Lean Management in the Romanian Industry. In: T. Koch, ed. 2008. Lean Business Systems and Beyond. New York, NY: Springer. pp.269-276.

Mayo, A. J. and Nohria, N., 2005. In Their Time: The Greatest Business Leaders of the Twentieth Century. Boston, MA: Harvard Business School.

McCraw, T. K. and Childs, W. R., 2018. American Business Since 1920: How It Worked. Hoboken, NJ: Wiley Blackwell.

Naruo, S. and Toma, S.G., 2007. From Toyota Production System to Lean Retailing: Lessons from Seven-Eleven Japan. In: J. Olhager and F. Persson, eds. 2007. Advances in Production Management Systems. New York, NY: Springer, pp.387-395.

National Academy of Engineering, 2004. The Engineer of 2020: Visions of Engineering in the New Century. Washington, DC: The National Academies Press. [pdf] Available at: $<$ https://inside.mines.edu/UserFiles/File/Assessment/Engr2020.pdf $>$ [Accessed 28 March 2021].

National Society of Professional Engineers, 2013. Professional Engineering Body of Knowledge. [pdf] Available at: <https://www.nspe.org/sites/default/files/resources/nspe-body-of-knowledge.pdf $>$ [Accessed 23 March 2021].

Nevins, A., 1954. The Times, the Man, the Company. New York, NY: Charles Scribner's Sons.

Roser, C., 2017. "Faster, Better, Cheaper" in the History of Manufacturing: From the Stone Age to Lean Manufacturing and Beyond. Boca Raton, FL: CRC Press.

Rubenstein, J.M., 2001. Making and Selling Cars: Innovation and Change in the US Automotive Industry. Baltimore, MD: The Johns Hopkins University Press.

Rubenstein, J.M., 2014. A Profile of the Automobile and Motor Vehicle Industry: Innovation, Transformation, Globalization. New York, NY: Business Expert Press.

Sinclair, U., 1938. Le roi de l'auto (Henry Ford, the Flivver King). Paris: Éditions Stock.

Snow, R., 2013. Invented the Modern Age: The Rise of Henry Ford. New York, NY: Scribner.

Sorensen, C.E., 2006. My Forty Years with Ford. Detroit, MI: Wayne State University Press.

Tedlow, R.S., 2003. Giants of Enterprise: Seven Business Innovators and the Empires They Built. New York, NY: Harper Business.

Toma, S.G., 2005. Fordism, postfordism and globalization. Amfiteatru Economic, 7(17), pp.1335-138.

Toma, S.G., Grigore, A.M. and Marinescu, P., 2014. The emergence of scientific management in America. Manager, 19, pp.127-131.

Toma, S.G., 2015. Apariția managementului științific. In: P. Marinescu and S.G. Toma, ed. 2015. Management. București: Editura Universității din București. pp.9-36.

Toma, S.G. and Naruo, S., 2017. Total quality management and business excellence: The best practices at Toyota Motor Corporation. Amfiteatru Economic, 19(45), pp.566-580.

Votolato, G., 2015. Car. London: Reaktion Books.

Watts, S., 2006. The People's Tycoon: Henry Ford and the American Century. New York, NY: Vintage.

Winicott, M., 2015. Henry Ford: Entrepreneurship Lessons. Madrid: Unitexto Digital Publishing. 